\title{
ESTHER GREENWOOD'S DISTASTE OF LIFE AS SEEN IN SYLVIA PLATH'S THE BELL JAR
}

\author{
Silvia Lubaba \\ UIN SunanAmpel Surabaya \\ silvilubaba50@gmail.com
}

\begin{abstract}
This study attempts to analyze the causes and the effect of Esther Greenwood's distasteful feelings. The aims of this study are to understand what makes Esther has distaste of life including toward men, her friends, her mother and the general social's perspectives. It also explains the effect of Esther's distaste. This study uses descriptive qualitative method. Things that will be done are describing the causes and effect of Esther's distaste using Sigmund Freud's psychoanalysis. After analyzing the data, the result shows that Esther Greenwood has distaste for her life because of her unconscious mind. She got a lot of influences from her bad experiences including the time she spent with her ex-boyfriend, her mother, her friends, and also her opposite views toward the social perspectives. Then, the effect of Esther's distaste is that she tends to use defense mechanisms such as denial, fantasy, reaction formation, rationalization, repression, displacements, sublimation, undoing, and acting out, every time her distasteful feelings show up.
\end{abstract}

Keywords: distaste of life; unconscious mind; defense mechanism

\section{INTRODUCTION}

Ideal life is defined as the perfect life wished by many people in this world. Sergio Calderon in "The SIS Times: How Would an Ideal Life Be?" states that an ideal life might be different for different people, depending on what people want but the most important thing is that everyone wants to achieve their own ideal life. For those who are not able to do so, they may grow along with distaste for their life. This happens to the main character's life in The Bell Jar, Esther Greenwood.

Sylvia Plath's The Bell Jar has many issues to explore. The novel is an exploration of the divide between mind and body. When readers read the whole story, they will find out how Esther loses control over her body as she grows into mental illness. She becomes unable to sleep, read, eat, or write in her own handwriting. She even tries to commit suicide.

In the case of Esther Greenwood, many people think that she has a great life. She gets scholarships and also an opportunity to work on New York. In contrast, Esther Greenwood has distasteful feelings toward many things in her life including men, her mother, her friends and the general social's perspectives. A problem then comes up relating to how Esther ends up hating her own life and what kind of effect does her distaste give to Esther's life. By 
knowing the causes and the effect of the distasteful feelings, this study is hoped to be useful to those who want to make it as reference for the next research relating to psychoanalysis theory as it is used here. Then, relating to the issue brought up here that is 'distaste', this study is also hopefully able to help those who have the same problem as Esther Greenwood that is a distaste of life.

\section{REVIEW OF LITERATURE}

It is explained previously that this study is going to use psychoanalysis as the theoretical basis. Psychoanalysis was firstly used by Sigmund Freud (Abrams, 1999:248). Rajeevan in the thesis entitled Yoga and Psychoanalysis: The Dynamics of Transcending the Present (2010:96) explained that B.A Farrell states that psychoanalysis is considered to be a high level theory containing various sub theories such as 'levels of consciousness', 'psychic structure of personality', 'psychosexual development', 'defense mechanisms' and 'theory of instincts', and it serves to unify them to some areas.

Here, the sub theories that will be chosen are Sigmund Freud's concept of unconscious mind and defense mechanisms. The unconscious refers to a mental process of which we are not aware of (Cloninger, 2004:35). Duane P. Schultz and Sydney E. Schultz (2005:54) state that unconscious mind contains the major motives behind our all behavior and is the repository of forces we cannot control. Unconscious mind itself is the largest part of people's mind. As being cited in The Unconscious Mind by John A. Bargh and Ezequil Morsella, the unconscious mind is viewed as the shadow of a "real" conscious mind (2008:01). Actually, human's behaviors are combined by conscious and unconscious minds (Cloninger, 2004:35). These two may act together well or smoothly but the combination may also interfere one to another. This conflict then produces irrational thoughts and behaviors. And when irrational thoughts or behaviors are in mind, people tend to use defense mechanisms to protect their self - esteem.

Defense mechanism is unconscious activities. They are individuals; each people use different sets of defense mechanism. Cramer in the journal entitled "Seven Pillars of Defense Mechanism Theory" states that defense mechanisms are cognitive processes that function to protect the individual from the excessive anxiety or other negative emotions (2009:12). As being cited by Baumeister, Dale and Sommer in Freudian Defense Mechanisms and Empirical Findings in Modern Social Psychology: Reaction Formation, Projection, Displacement, Undoing, Isolation, Sublimation, and Denial (1998:1082), Fenichel states that 
defense mechanisms are actually designed to protect self - esteem. Sigmund Freud and his daughter, Anna Freud divides those mechanisms into numbers which are listed as follows:

\section{Repression}

Repression is when the ego keeps and represses the unwanted desires within unconscious mind and does not let it reach on the consciousness.

\section{Reaction formation}

This kind of defense mechanism involves the changing the impulses which are not accepted socially into the opposite (Schultz, 2005:59).

\section{Displacement}

Displacement distorts the objects of the drive. It refers to changing the target of an impulse.

\section{Projection}

Projection is when someone has uncomfortable feelings then they tend to project those feelings to other people. This is similar to attributing someone's thoughts or impulses to another person (Feist, 2008:37).

\section{Denial}

Denial is one of the defense mechanisms which is very common in daily life. It is simply refusing the event occurred. It is denying a painful reality (Schultz, 2005:59).

\section{Fantasy}

Fantasy loses the anxieties or other negative emotions by imagination. Fantasy is done by gratifying unfulfilled needs withimagined situations in which they are satisfied (Ewen, 2014: 22).

\section{Acting out}

Acting out is one of the defense mechanisms in which the unconscious mind protects itself against being uncovered by the ego. A person may perform an extreme behavior to express thoughts or feelings the person feels incapable of otherwise expressing.

\section{Rationalization}

Rationalization is explaining an unacceptable behavior in an acceptable way (Ewen, 2014:60).

\section{Intellectualization}

Robert B. Ewen in his book entitled, An Introduction to Theories of Personality states that intellectualization is when a person unconsciously separates threatening emotions from the associated thoughts or events and reacts on only an intellectual level (2014:22). 


\section{Undoing}

This kind of defense mechanisms is defined as adopting a behavior that negates the previous act or thought (Ewen, 2014:21). In other words, undoing is taking back the behaviors or thoughts that are hurtful.

\section{Identification}

Identification is defined as a process of borrowing one's identity with that of someone else.

\section{Regression}

In regression, there is a movement from mature behavior to immature behavior (Ryckman, 2008:43).

\section{Sublimation}

It is the process of transforming libido into "socially useful" achievements (Ryckman, 2008:43).

\section{Compensation}

The function of compensation is to enhance someone's self - esteem by overcoming a person's failure in one area of behavior through satisfaction achieved in another area (Simma, 2009:28).

\section{DISCUSSION OF MAIN THEMES}

Sylvia Plath's The Bell Jar tells about a girl's life named Esther Greenwood who has to struggle with her own life and deal with a lot of things she does not like. Esther is raised by her mother ever since her father passed away when she was nine years old. Her love life goes around a man named Buddy Willard who creates a lot of disappointments in Esther's life and gives influences to Esther Greenwood. Most of Esther's disappointments on her past which could not be expressed by her then stored in her unconscious mind. Esther throws it in a form of distaste to men, her friends, her mother and the general social's perspectives. This analysis tries to dig out the causes and the effect of Esther Greenwood's distaste of life by taking the data from the novel itself, that is The Bell Jar written by Sylvia Plath which was published in 1963.

\subsection{The Causes of Esther Greenwood's Distaste of Life}

In The Bell Jar, it is explained that Esther Greenwood feels like being isolated from connecting with other people and being prevented to see the world from her own perspective. Her distaste of life becomes worse until she decides to commit suicide. This analysis attempts 
to find out the causes of Esther Greenwood distaste of life which is influenced by her unconscious mind. Esther Greenwood's distaste of life and the causes are explained as follow:

\section{Esther Greenwood's feelings to men}

One thing happened to Esther Greenwood's past was that when she felt like she would not be able to find a man she wanted after being betrayed by her ex - boyfriend named Buddy Willard. Buddy Willard is a man whom Esther dreams of. She adores Buddy very much till he creates a lot of disappointments in Esther's life. Buddy has had an affair with other women and that fact really disappoints Esther.

Esther finds it out when she asks Buddy about having affair with another woman, "Suddenly, I said, "Have you ever had an affair with anyone, Buddy?" (37). Esther's question explains how Esther suddenly asks Buddy about having an affair. Esther Greenwood expects Buddy to be the real innocent man who has never been in affair, "I expected him to say, "No, I have been saving myself for when I get married to somebody pure and a virgin like you." (37). She wants Buddy to be someone who will likely save himself until he gets married.

Buddy's answer is unexpected for Esther, "Well, yes, I have," Buddy said finally. I almost fell over..." (37). Buddy Willard has had an affair. He even sleeps with another woman. This fact makes Esther think that Buddy is not as innocent as she thinks he should be. Esther feels like she is fooled by Buddy since heacts as an innocent man, "Buddy Willard was a hypocrite. Of course, i didn't know he was a hypocrite at first. And then just as he was looking at me more and more $\mathrm{i}$ discovered quite by accident what an awful hypocrite he was...”(28).

That is why she feels more disappointed and it gives influences to the way Esther sees men later when she meets a man named Marco.Esther Greenwood labels Marco as a woman hater, "I could tell Marco was a woman-hater, because in spite of all the models and TV starlets in the room that night he paid attention to nobody but me." (56). This happens when Marco only pays attention to her and ignores other women. She easily decides to say that Marco is a man who hates women, "I began to see why woman-haters could make such fools of women. Woman - haters were like gods: invulnerable and chock-full of power. They descended, and then they disappeared. You could never catch one." (56)

In Esther's perspective, men whom she labels as woman - haters are like Gods. They cannot be harmed and are full of power. But once they disappear, no one will be able to catch them. Woman - haters can get women fooled because they seem untouchable. Her meeting with Marco then brings Esther back to her past when Buddy also treated her as his only girl yet in fact Buddy also had other women. 


\section{Esther Greenwood's Feelings to her Friends}

Esther lives in New York along with her friends. One of them is Doreen. Unfortunately, Esther considers Doreen as her problem. Doreen's physical appearance is even disturbing for Esther Greenwood. She is described as a girl who comes from a college in the South, has eyes like transparent agate marbles, and smiles as if she is mocking someone. So, Esther cannot stand with it. In Esther's perspective, Doreen is a very silly girl who will tell a joke to everyone she wants and it singles out Esther right away (04).

Esther Greenwood is holding everything she dislikes about Doreen in her heart, but this grows more and more, that day by day Doreen is seen as a bad girl in Esther's eyes. Esther's distaste to Doreen is caused by her unconscious mind in which at the time, Esther cannot express what she feels about Doreen and only holds it by herself. Here is Esther's statement about Doreen.

"Doreen looked terrific. She was wearing a strapless white lace dress zipped up over a snug corset affair that curved her in at the middle and bulged her out again spectacularly above and below, and her skin had a bronzy polish under the pale dusting powder. She smelled strong as a whole perfume store..." (06)

When they go to a party, Esther realizes how terrific Doreen is as a girl. Doreen is indeed a type of a girl who is acting out differently from the other girls even in her way she dresses up. This is a very nauseating thing for Esther Greenwood because at that time Doreen's dress is too much while Esther just wears forty-dollar dress she bought before going to New York.

Esther Greenwood is also distracted by her other friends in hotel. The girls who are living with her are from wealthy families and Esther has a distasteful feeling to this condition, "These girls looked awfully bored to me. I saw them on the sunroof, yawning and painting their nails.... I talked with one of them, and she was bored with yachts and bored with flying... Girls like that make me sick." (04).

Esther Greenwood also feels jealous of those friends who easily go anywhere they want even go skiing in overseas. Esther Greenwood cannot speak when she is with her friends in the hotel, "Girls like that make me sick. I'm so jealous I can't speak. Nineteen years, and I hadn't been out of New England except for this trip to New York. It was my first big chance, but here I was, sitting back and letting it run through my fingers like so much water." (04)

Esther has a jealous feeling to the other girls who are indeed coming from high class society. She has not ever been anywhere except New York. The jealousy grows more when Esther cannot even do anything in New York. She is just staying there as someone who gets a scholarship prize in New York while other girls can go anywhere they want. 
Esther Greenwood also has distasteful feeling toward her friend named Joan Gilling. In Esther's mind, Joan is a girl who turns Buddy away from her because Buddy has ever asked Joan Gilling to go to prom. "Oh, I can't do that. I'm up here for the Sophomore Prom with Joan...” (31). At that time, Buddy met Esther and talked to her, but Esther was disappointed when Buddy said that actually he was there to meet Joan. This then put distaste in Esther's feeling towards Joan Gilling.

\section{Esther Greenwood's feelings to her mother}

Esther Greenwood is only raised by her mother. Ever since her father died when she was nine, Esther spends most of her time witnessing her mother struggles for their life as a family. Esther loves her mother for raising her, but on the other side she also has distasteful feeling toward her mother. Esther's mother is actually a type of mother who always talks to her daughter sweetly. However, there are also many times when she does not tell the truth to Esther, "My mother took care never to tell me to do anything. She would only reason with me sweetly..." (64). From Esther's words, her mom is described as a woman who says everything nicely in front of her. She never asks Esther Greenwood to do anything, but she also does not tell the exact truth to Esther.

One thing that also contributes to Esther's distaste towards her mother is when her mother keeps begging her to do a treatment in the hospital. Deeply in her heart, Esther does not want to do the treatment anymore but her mother keeps insisting that Esther have todo it(77). All of the things related to Esther Greenwood's mother then grow in Esther's mind as a distaste. The things she has been holding up about her mother blow up in a form of distaste. The peak is when Esther isin shock treatment. Slowly, she hates her mother. Her unconscious mind plays the role.

Esther Greenwood does not want to be visited by her mother. She hates her mother for not understanding her feelings well and also for acting out as a very good mother when she does not even know what her daughter wants.

"That was a silly thing for her to do," I said to Doctor Nolan. Doctor Nolan nodded. She seemed to know what I meant. "I hate her," I said, and waited for the blow to fall. But Doctor Nolan only smiled at me as if something had pleased her very, very much, and said, "I suppose you do."(107)

One day, Esther Greenwood's mother brings her roses. Esther asks her to save the roses for Esther's funeral. But then, her mother's face puckers and she is about to cry. Esther thinks that what has been done by her mom is so silly after everything that has happened between them. Then, she says to her psychiatrist named Doctor Nolan that she hates her mother. 
Esther Greenwood's distasteful feeling to her mother grows slowly. Even though Esther spends her days by knowing how hard her mother struggling for their life, but the way her mother treats her disappoints her. As a daughter, Esther Greenwood does nothing. She is just a daughter after all. It is impossible for her to be a rebellious person. This is then stored in her mind and she throws it in a form of distaste to her mother.

\section{Esther Greenwood's Feelings to the Social Perspectives}

As a girl who grows up normally, Esther always has her own dreams towards the society. She hopes that the society will have the same perspective as her. But then, she gets very disappointed that in the fact there are many things exist in the society which are the opposite of her own point of view. Esther Greenwood hates the society's perspective about woman's virginity.

In her past, Esther was being overhyped towards Buddy Willard. Till then, Buddy made her disappointed. In Esther's eyes, Buddy had lost his virginity and it was unexpected for her, "And that's how Buddy had lost his pureness and his virginity... At first I thought he must have slept with the waitress only the once, but when I asked how many times, just to make sure, he said he couldn't remember" (37).Esther feltmore disappointed when Buddy did not even remember how many times he had slept with other women. Something about it made Esther feel sick since Buddy was pretending as a very pure man while in fact, he was not even able to keep his virginity.

Because of this experience, Esther states how she actually does not agree with the perspective of the society about a woman's virginity. Generally, the society sees a pureness is a must for a woman. Esther thinks that when a woman has been struggling to defend her pureness or virginity, but it turns out that the man she is marrying with has been doing sex with another women, it will be unfair for the woman. This is why she does not agree with the general opinion about the purity of a woman, "It might be nice to be pure and then to marry a pure man, but what if he suddenly confessed he wasn't pure after we were married, the way Buddy Willard had?...” (43).

\subsection{The Effect of Esther Greenwood's Distaste of Life}

Esther Greenwood might feel free to have a distaste in her life.But as a girl who lives along with the society, Esther's distasteful feelings cannot be fully expressed since it may put her in both anxiety and conflict with others because Esther's distaste will disturb her life and worsen her relationship with other people. As the effect of this, Esther Greenwood then tends to use defense mechanisms in her daily life. 


\section{Repression}

Esther throws a repression towards her feeling for Joan Gilling. This can be resulted by her distaste toward her friends in the past including Doreen and Betsy. When she meets Joan in the hospital for treatment, she does some talks with Joan. They talk about the time when Joan will leave the hospital.

"Joan grew wistful "You'll come visit me, won't you, Esther?"

"Of course."

But I thought, "Not likely." (118)

Esther does not let out her feeling that she will not visit Joan to her conscious mind. She represses her thoughts. Here, Esther does the repression by saying another statement to Joan. So, she does not speak out what is really on her mind.

\section{Reaction formation}

Esther shows reaction formation when she treats her mother well even though Esther has been feeling disappointed with her mother since she was a child. Deeply, in her heart she feels disappointed because her mother did not cry for her father's death (88). Here, Esther tries to change her distaste into something more acceptable because treating a mother well is a good thing and well - received by all people. Same thing goes to Esther's treatment to her friends. Even though she has been feeling uncomfortable with some of her friends, she still gives them a good treatment because that is more acceptable.

\section{Displacement}

Esther Greenwood also has distaste to the visits she has received when she is on her treatment at hospital. Esther is often visited by her mother and even other people she does not want to meet. Unexpectedly, she is also visited by a man named George Bakewell. As the effect of this distaste, Esther projects her uncomfortable feelings to the nurse of the hospital. She does something rudely to the hospital's nurse (96-97). She does it on purpose because she does not like being in the hospital and gets visited by many people.

\section{Denial}

Actually, Esther Greenwood seems to havea habit in denying the reality happens in her life since she was very young. Esther gets a lot of disappointment from her boyfriend, Buddy Willard. Buddy has had an affair with other women. Esther tries to cover her disappointment by denying the fact that it is Buddy who starts the affair, "Of course, somebody had seduced Buddy, Buddy hadn't started it and it wasn't really his fault. It was this waitress at the hotel he worked at as a busboy the last summer at Cape Cod..." (37). Esther convinces herself that it 
is the waitress first who seduces Buddy. She denies the fact that Buddy is indeed a hypocrite man who has an affair with other women.

\section{Fantasy}

In dealing with her distaste of life, Esther Greenwood also tries to gratify her unfulfilled needs by imagining the things that satisfy her. Relating to her distaste to men, Esther imagines that her love story with Buddy will be like a love story between a Jewish man and a nun.

"It seemed to me Buddy Willard and I were like that Jewish man and that nun, although of course we weren't Jewish or Catholic but Unitarian. We had met together under our own imaginary fig tree, and what we had seen wasn't a bird coming out of an egg but a baby coming out of a woman, and then something awful happened and we went our separate ways." (30)

Esther describes her relationship with Buddy as the story of a Jewish man and a nun she has read from Ladies' Days. The story itself talks about a Jewish man and a nun who meet under the fig tree for picking the figs until one day they see the little bird pecks its way out of the egg, they touch the backs of their hands together. Then suddenly the nun does not come againto pick the figs. They get separated.

As the effect of Esther's distaste toward Buddy, she creates her own fantasy that her relationship with Buddy will be over just like what happensto the Jewish man and the nun. Of course, it is not exactly the same as that story but it might be turning out that way. In Esther's imagination, her story with Buddy will be over after they both witness a woman gives birth to her baby not after watching the little bird pecks its way out of the egg. By having this kind of imagination, Esther feels satisfied about it.

\section{Acting out}

Acting out is a kind of defense mechanisms in which a person will perform an extreme behavior to express his or her feelings. Firstly, Esther Greenwood does this when she cannot bear with her situation anymore. In covering her distaste towards many things in her life including her mom, friends, men and also her different perspectives from the society, Esther commits suicide. She does try to kill herself for many times.

Esther always feels curious about suicide. She collects some papers in which they talk about suicide (72). "I thought drowning must be the kindest way to die, and burning the worst...That morning I had tried to hang myself..." (83). So, not only reading papers about suicide and the ways to do it, Esther has also been trying to kill herself. "The only thing to do was to drown myself then and there..." (85). She tries to commit suicide by drowning herself when she is swimming with her friends. 


\section{Rationalization}

Rationalization is done by making something seemed more rational by thought. Esther Greenwood is a type of a girl who has an opposite perspective from society that a woman should be virgin before she gets married. This is resulted by her experience when she was fooled by Buddy Willard. Here is Esther's statement, "I couldn't stand the idea of a woman having to have a single pure life and a man being able to have a double life, one pure and one not..." (43).

Esther cannot stand the idea that women should be virgin till they get married. Her choice is that she loses her virginity. She rationalizes her own perspectives. Esther defends herself by stating that a girl should not be virgin, because it is unfair if the girlsare virgin while the men they want to get married with are not virgin. By making her own statement, Esther tries to rationalize that it is indeed an unfortunate for a woman who keeps her virginity until marriage while her partner is not virgin anymore.

\section{Undoing}

Esther Greenwood shows undoing when she hates her friend named Betsy at first, but then she takes it back by stating that Betsy resembles her more than her other friend, Doreen. "Deep down, I would be loyal to Betsy and her innocent friends. It was Betsy I resembled at heart..." (12). At first, Esther has a distasteful feeling towards Betsy's personality who easily gets interested just because of a simple thing (04). But then, when she feels disappointed towards Doreen, she takes her opinion back and states that she has more similarities to Betsy than Doreen. It is obvious that Esther does this because she is afraid that her own thoughts about Betsy will harm her and makes her have no friends.

\section{Sublimation}

A person does sublimation when she or he changes the unpleasant impulses into more acceptable directions. This is done mostly by doing positive things. As being explained previously that Esther has distasteful feelings to men. When she broke up with Buddy, Esther covered her feeling by working so hard. "When I stayed in to study on Saturday nights they were extremely kind to me because they thought I was so brave, working the way I did just to hide a broken heart...” (39). Here, Esther Greenwood changes her distasteful feelings by working hard till others think that Esther is indeed a hard - working girl while in Esther's mind, she does it because she wants to hide her broken heart. 


\section{CONCLUSION}

The analysis of this research focuses more on the causes and the effects of Esther Greenwood's distaste of life. After analyzing the novel, it is concluded that Esther's distaste is caused by her unconscious mind. Many things happened in the past such as things with Buddy Willard as her ex - boyfriend which disappoint her and influence her perspectives about men. Then, some disappointments of Esther also lead to distasteful feelings to her friends and her mother. The last is that her opposite opinions toward the social perspectives which cannot be expressed also results in her distaste to the general public's opinion.

Esther Greenwood's distaste of life also shows effect. In this case, she uses defense mechanisms every time her distasteful feelings show up. Some of the defense mechanisms used by Esther Greenwood are repression, reaction formation, denial, fantasy, acting out, displacement, rationalization, undoing and sublimation. Esther Greenwood's distaste of life then results in the defense mechanisms used by her.Defense mechanisms are used by people to protect their self - esteem every time irrational thoughts such as a distasteful feeling show up.

\section{REFERENCES}

Abrams, M. H. (1999). A Glossary of Literary Terms.New York: Earl Macpeek.

Bargh, J. A. \& Morsella, E. (2008). Perspectives on Psychological Science: A Journal of the Association for Psychological Science: The Unconscious Mind. Retrieved September 10, 2016 from http://www.ncbi.nlm.nih.gov/pmc/articles/pmc2440575

Baumeister, R. F., Dale, K., \& Sommer, K. L. (1998).Freudian Defense Mechanisms and Empirical Findings in Modern Social Psychology: Reaction Formation, Projection, Displacement, Undoing, Isolation, Sublimation, and Denial. Case Western Reserve University.

Calderon, S. (n.d.). The SIS Times: How Would an Ideal Life Be. Retrieved September 10, 2016 from http://www.sistimes.weebly.com/how-would-an-ideal-life-be.html

Cloninger, S.C. (2004). Theories of Personality: Understanding Persons (4 ${ }^{\text {th }}$ edition).New Jersey: Pearson Prentice Hall.

Cramer, P. (2009). Seven Pillars of Defense Mechanisms Theory. Retrieved September 10, 2016 from http://www.psychomedia.it/rapaport-klein/cramer09.pdf

Ewen, R.B. (2014).An Introduction to Theories of Personality ( $7^{\text {th }}$ edition). New York and London: Taylor \& Francis Group. 
Feist, J. \& Feist, G.J. (2008). Theories of Personality (7 $7^{\text {th }}$ edition). New York: McGraw-Hill Companies.

Plath, S. (1963). The Bell Jar. London: William Heinemann Limited.

Rajeevan, E. (2010). Yoga and Psychoanalysis: The Dynamics of Transcending the Present. Retrieved September 10, 2016 fromhttp://hdl.handle.net/10603/2569

Ryckman, R. M. (2008). Theories of Personality (9 $9^{\text {th }}$ edition). New York: Thomson Wadsworth.

Schultz, D. P. \& Schultz, S. E. (2005). Theories of Personality (8 ${ }^{\text {th }}$ edition). New York: Wadsworth Cengage Learning.

Simma, W. (2009). An Analysis of Defense Mechanisms Used by the Main Characters in Mark Twain's The Adventures of Huckleberry Finn and The Prince and ThePauper.Master of Arts degree in English at Srinakharinwirot University. 